\title{
ALTERATIONS OF TOTAL ANTIOXIDANT CAPACITY OF PATHOGEN CULTURES UNDER THE INFLUENCE OF NOVEL CHEMICAL COMPOUNDS
}

\section{Carolina LOZAN-TIRSU}

Department of Microbiology and Immunology, Nicolae Testemitanu SUMPh, Chisinau, Republic of Moldova Corresponding author: Carolina Lozan-Tirsu, e-mail: carolina.lozan@usmf.md

DOI: $10.38045 /$ ohrm.2020.1.16

UDC: $579.61: 546-3$

Keywords: antimi- Introduction. The major and most common mechanisms for almost all antimicrobial crobial activity, substances is the induction of oxidative stress responses within the pathogen cells by acantioxidant activity, cumulation of free radicals, which mediate a whole range of classical antimicrobial mechchemical compounds, anisms of action observed by researchers. Thus, this present study was conducted to reveal copper, reference some biochemical changes regarding the antioxidant status of pathogenic microorganisms strains. under the influence of novel chemical compounds selected.

Material and methods. The copper (II) coordination compounds were included as in vitro study material, namely, Co (II), Zn (II) and aromatic propenones, synthesized at the Department of Inorganic Chemistry, the State University of Moldova. The antimicrobial properties were tested on five reference strains. The ABTS test was applied to determine the antioxidant activity, thus determining the total antioxidant capacity using the ABTS"+ cation radical.

Results. The most vulnerable to high-intensity oxidative stress are the reference strains of Staphylococcus aureus ATCC 2592 and Bacillus cereus ГИСК 8035, the most resistant being the reference culture Salmonella enterica (S. Abony ГИСК 03/03y).

Conclusions. The study results showed that the selected compounds might substantially reduce the total antioxidant capacity in the studied reference cultures.

Cuvinte cheie: activitate antimicrobiană, activitate dantă, antioxichimici, cupru, tulpini de referință.
MODIFICAREA CAPACITĂȚII ANTIOXIDANTE TOTALE A CULTURILOR DE MICROORGANISME PATOGENE SUB INFLUENȚA COMPUȘILOR CHIMICI NOI

Introducere. Unul dintre mecanismele, generale și comune, pentru majoritatea preparatelor antimicrobiene, este inducerea stresului oxidativ în celulele patogene, exprimat prin acumularea în exces a radicalilor liberi, care mediază întreg spectrul clasic de mecanisme de acțiune antimicrobiană, observate de cercetători. Astfel, a devenit oportună realizarea unui studiu, care ar elucida unele modificări biochimice, ce reflectă statutul antioxidant al microorganismelor patogene sub influența compușilor chimici noi selectați.

Material și metode. În calitate de obiecte de studiu in vitro au servit compușii coordinativi ai Cu (II); Co (II), Zn (II) și propenonele aromatice, sintetizate la Catedra de chimie anorganică de la Universitatea de Stat din Moldova. Efectele antimicrobiene au fost testate pe 5 tulpini de referință. Pentru determinarea activității antioxidante a fost aplicat testul ABTS, care stabilește capacitatea antioxidantă totală, cu utilizarea radicalului cation $A B T S^{\circ}+$.

Rezultate. Cele mai vulnerabile, din punctul de vedere al instalării stresului oxidativ de înaltă intensitate, sunt culturile de referință Staphylococcus aureus ATCC 2592 și Bacillus cereus ГИСК 8035, cea mai rezistentă fiind cultura de referință Salmonella enterica (S. Abony ГИСК 03/03y).

Concluzii. Analizând rezultatele prezentate mai sus, putem afirma că, sub acțiunea compușilor selectați, se produce o reducere substanțială a capacității antioxidante totale în culturile de referință studiate. 


\section{INTRODUCTION}

Currently, there is an increasing interest regarding the synthetic chemical compounds, including several perspective categories. Recent studies have reported that different metals might cause multiple disorders of microbial cells. The oxidative stress, protein dysfunction and cell membrane damage are the most common causes of that, being generated by the action of metal ions (1).

Copper is a transition metal with pronounced biological effects. Its biological activity has been confirmed by its copper ion-binding ability to combine with biomolecules, particularly to proteins and nucleic acids to form various complexes $(2,3,4)$.

Current interest in $\mathrm{Cu}$ complexes has derived from their potential use as antimicrobial, antiviral, anti-inflammatory, antitumor, inhibitory agents of different enzymes (5). It is well-known that $\mathrm{Cu}$ (II) complexes of non-steroidal antiinflammatory drugs show both a high antiinflammatory activity and a low toxicity degree towards healthy tissues. Although the antiinflammatory effect of $\mathrm{Cu}$ compounds are quite promising, the latest researches have been focused on the potential chemotherapeutic properties of copper-based compounds. Theoretical studies related to the development, synthesis and testing of the copper complexes are considered promising in obtaining active antiviral and antimicrobial drugs, including for HIV, H1N1 treatment, as well as for multidrug-resistant bacteria $(6,7,8)$.

Copper complexes exhibit diverse in vitro biological activities, ranging from antibacterial and anti-inflammatory to cytostatic and some enzyme inhibitory properties. Copper compounds (due to copper ion) interact directly with proteins and DNA at the molecular level, which leads to their structural distortion. The indirect mode of action of copper compounds shows the same effects on biopolymers, as in direct coupling, however generated by reactive oxygen species, formed in presence of $\mathrm{Cu}$ (II) ions (5).

The aforementioned arguments were the selection criteria for the present study, namely the coordination copper (II) compounds with different ligands and aromatic propenones, showing potential antimicrobial effects on reference strains and clinically isolated strains of patho- genic microorganisms. It is highly important to highlight the characteristics and mode of action of new antimicrobials both in assessing the therapeutic effects and in promoting a new pharmaceutical product by its implementing into therapy practice $(5,6,7,8)$.

\section{MATERIAL AND METHODS}

The copper (II) coordination compounds were included as in vitro study material, namely, Co (II), Zn (II) and aromatic propenones, synthesized at the Department of Inorganic Chemistry, at State University of Moldova. The antimicrobial properties were tested on five reference strains viz. Staphylococcus aureus ATCC 25923, Bacillus cereus ГИСК 8035, Escherichia coli AТСС 25922, Shigella sonnei ATCC 25931, and Salmonella enterica (S. Abony ГИСК 03/03), which come from two culture collections, recognized as quality biological material used for research studies: American Type Culture Collection (ATCC, USA) and the State Collection of Pathogenic Microorganisms of L. A. Tarasevici State Institute of Scientific Research on Standardization and Control of Biological medical preparations ГИСК, Russian Federation.

The ABTS assay (2,2-Azino-bis-3-ethylbenzothiazoline-6-sulfonic acid) to determine the antioxidant activity (9) was carried out. The ABTS ${ }^{+}$ cation radical testing was used to identify the total antioxidant capacity, as it allows assessing the multicomponent extracts, as in the studied cell lysate.

Oxidized ABTS (ABTS +) (2,2-Azino-bis-3-ethylbenzothiazoline-6-sulfonic acid) was generated by the radical ABTS. The formed radical was reduced by the mechanism of electron addition. Trolox, a water-soluble compound with antiradical activity similar to tocopherol was used as an equivalent for quantitative assessment. The test findings were expressed in terms of percentage inhibition (in order to compare the test results) and TEAC (trolox equivalent antioxidant activity) to compare with other antioxidants.

An $\mathrm{ABTS}^{-}+$cation radical was generated by oxidation of ABTS with potassium persulfate. Therefore, $7 \mathrm{mM}$ ABTS stock solution in deionized water was prepared with $2.45 \mathrm{mM}$ potassium persulphate in a ratio of $1: 1$. The ABTS radical formation occurred for $16 \mathrm{~h}$ at room temperature in darkness. The working solution was 
prepared from ABTS stock solution dissolved in ethanol or distilled water until the absorbance value ranged between at $0.700 \pm 0.020$ units to the wavelength of $734 \mathrm{~nm}$.

$0.3 \mathrm{ml}$ of bacterial extract and $2.7 \mathrm{ml}$ of ABTS solution were assessed. The reduction reaction occurred for $6 \mathrm{~min}$ at room temperature, whereas the inhibition percentage was calculated according to the following equation: $\%$ inhibition = $\left(\mathrm{Abs}_{\mathrm{t}=0}-\mathrm{Abs}_{\mathrm{t}=6 \text { min. }}\right) / \mathrm{Abs}_{\mathrm{t}=0} * 100$, Whereas, $\mathrm{Abs}_{\mathrm{t}=0}$ min. is the absorbance value ranging between $0.700 \pm 0.020$ at $734 \mathrm{~nm} \mathrm{ABTS}^{\circ}$ solution, and $\mathrm{Abs}_{\mathrm{t}=6 \text { min }}$ is the absorbance value after incubition.
The TEAC index was expressed as $\mu \mathrm{M}$ Trolox/mg biomass and calculated using Trolox standard calibration curve.

To avoid separation, drying and weighing of pathogenic cultures, the pathogenic dry weight was determined indirectly by calculating the average cell volume and applying the density value $\rho=1$. The average cell size, volume and weight used within the study are presented in Table 1. The following table also includes the cell mass found in McFarland standard in ml for each culture.

Table 1. Estimated parameters of microbial biomass.

\begin{tabular}{|c|c|c|c|c|c|c|}
\hline \multirow{2}{*}{ Culture } & \multicolumn{4}{|c|}{ Cell parameters } & \multirow{2}{*}{$\begin{array}{c}\text { Cell mass, } \\
\text { mg }\end{array}$} & \multirow{2}{*}{$\begin{array}{c}\text { Culture mass } \\
\text { (mg) per } \\
\text { 0.5McF ml } \\
\text { standard }\end{array}$} \\
\hline & $\mathrm{r}, \mu \mathrm{m}$ & $\mathrm{h}, \mu \mathrm{m}$ & $\mathrm{V}, \mu \mathrm{m}^{3}$ & $\mathrm{~V}, \mathrm{~mm}^{3}$ & & \\
\hline $\begin{array}{l}\text { Staphylococcus aureus } \\
\text { ATCC } 25923\end{array}$ & $0.64 \pm 0.038$ & 0 & 0.6200 & $6.2^{*} 10^{-10}$ & $6.2 * 10-10$ & 0.093 \\
\hline $\begin{array}{l}\text { Bacillus cereus ГИСК } \\
8035\end{array}$ & $0.54 \pm 0.061$ & $3.5 \pm 0.2$ & 2.7475 & $2.7^{*} 10^{-9}$ & $2.7^{*} 10^{-9}$ & 0.405 \\
\hline $\begin{array}{l}\text { Escherichia coli ATCC } \\
25922\end{array}$ & $0.55 \pm 0.036$ & $2.7 \pm 0.3$ & 2.1195 & $2.12^{*} 10^{-9}$ & $2.12^{*} 10^{-9}$ & 0.318 \\
\hline $\begin{array}{l}\text { Shigella sonnei ATCC } \\
25931\end{array}$ & $0.37 \pm 0.020$ & $2.6 \pm 0.1$ & 0.73476 & $7.3^{*} 10^{-10}$ & $7.3 * 10^{-10}$ & 0.1095 \\
\hline $\begin{array}{l}\text { Salmonella enterica (S. } \\
\text { Abony ГИСК } 03 / 03 y)\end{array}$ & $0.54 \pm 0,010$ & $3.9 \pm 0.1$ & 3.0301 & $3.03 * 10^{-9}$ & $3.03^{*} 10^{-9}$ & 0.4545 \\
\hline
\end{tabular}

The necessary biomass amount was determined according to the method described in Table 1 in order to obtain the cell extracts. Cell extracts were obtained from biomass after being washed with phosphate buffered solution ( $\mathrm{pH} 7.0)$. Afterwards, the biomass (100 mg) was resuspended in phosphate buffer to destroy the cell wall and cytoplasmic membrane. Therefore, $0.1 \mathrm{~g}$ of glass beads, sized 150-212 $\mu$ m (Sigma) were applied. The beads were mixed with cell suspension in a vortex shaker for one minute, at 5-minute interval with ice cooling. The lysate was centrifuged for $10 \mathrm{~min}$ at $8000 \mathrm{rpm}$ at $4^{\circ} \mathrm{C}$, whereas the supernatant was refriger ated at $4^{\circ} \mathrm{C}$ until being used (10).

Bacterial cultures corresponding to 0.5 McFarland turbidity standard were subjected to new chemical compounds activity, being selected in a concentration equal to the MIC for each compound and reference culture. After a 2-hour contact time of the culture with the compounds, the concentration of the cells was adjusted according to the turbidity standard. Biomass was collected and processed according to the methods described above. New antibacterial chemical compounds were assessed. ABTS assay values were expressed as percent inhibition of ABTS + cation radical.

\section{RESULTS}

The study results obtained in assessing the new antimicrobial chemical compounds against the Staphylococcus aureus ATCC 25923-reference strain are shown in Figure 1.

There is a significant decrease in the antioxidant capacity of Staphylococcus aureus strains ATCC 25923, used in the treatment of cells with both Furacillin and selected new chemical compounds. The percentage inhibition of ABTS cation radical, when treated with Furacillin, accounted for $59.1 \%$ of the cell extract capacity of staphylococcus, untreated with antibacterial substances. The total antioxidant activity of the 
cell extracts obtained from the staphylococcus biomass treated with the 12 newly-selected chemical compounds ranged from 6.1 to $30.5 \%$ of the antioxidant capacity of the control strains.
13 new chemical compounds with high antibac terial effect were chosen for Bacillus cereus ГИСК 8035 reference culture. The study results obtained for the total antioxidant capacity of cell lysates are presented in Figure 2.

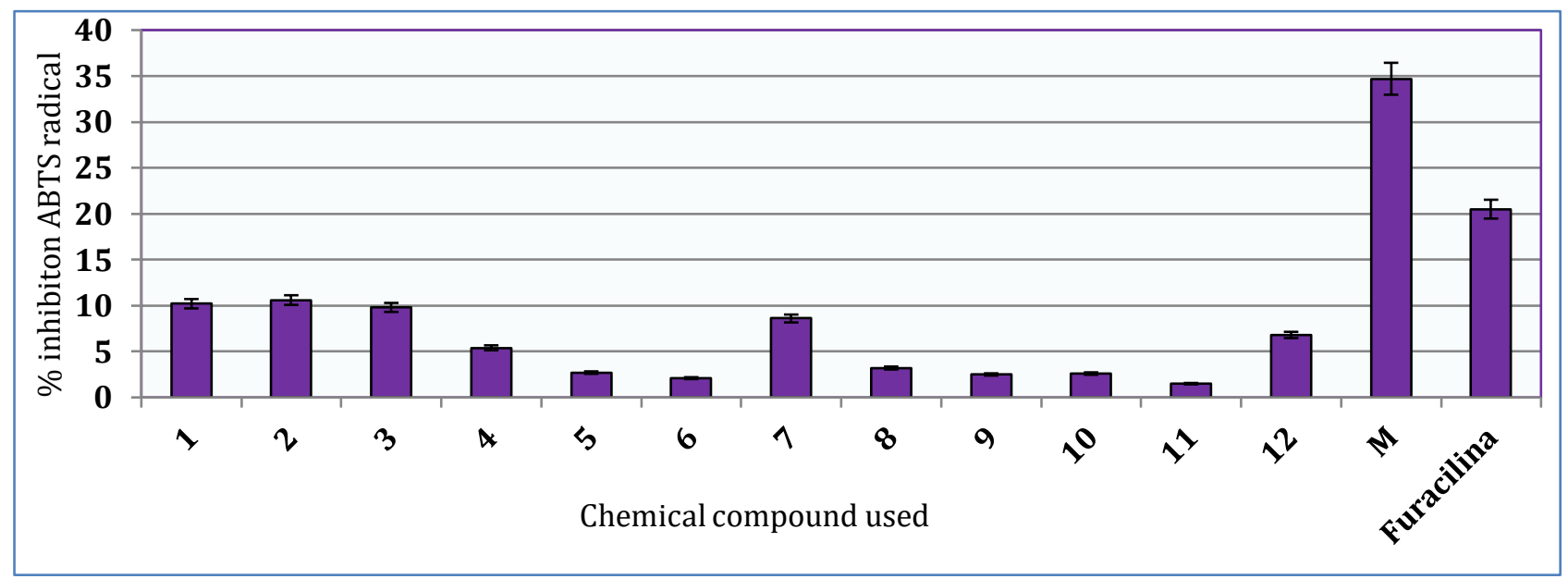

Figure 1. Alterations of total antioxidant capacity in Staphylococcus aureus strain ATCC 25923 under the influence of new chemical compounds: $1-\mathrm{C}_{38} \mathrm{H}_{38} \mathrm{Cu}_{2} \mathrm{~N}_{14} \mathrm{O}_{10} \mathrm{~S}_{4} ; 2-\mathrm{C}_{42} \mathrm{H}_{42} \mathrm{Cu}_{2} \mathrm{~N}_{14} \mathrm{O}_{12} \mathrm{~S}_{4} ; 3-$ $\mathrm{C}_{46} \mathrm{H}_{46} \mathrm{Cu}_{2} \mathrm{~N}_{18} \mathrm{O}_{10} \mathrm{~S}_{6} ; 4-\mathrm{C}_{46} \mathrm{H}_{42} \mathrm{Cu}_{2} \mathrm{~N}_{18} \mathrm{O}_{10} \mathrm{~S}_{4} ; 5-\mathrm{C}_{15} \mathrm{H}_{19} \mathrm{ClCuN}_{4} \mathrm{O}_{2} \mathrm{~S} ; 6-\mathrm{C}_{15} \mathrm{H}_{19} \mathrm{CuN}_{5} \mathrm{O}_{5} \mathrm{~S} ; 7-\mathrm{C}_{15} \mathrm{H}_{17} \mathrm{ClCuN}_{4} \mathrm{OS} ; 8$ $\mathrm{C}_{15} \mathrm{H}_{19} \mathrm{CuN}_{5} \mathrm{O}_{5} \mathrm{~S}(2,5) ; 9 \mathrm{C}_{15} \mathrm{H}_{19} \mathrm{CuN}_{5} \mathrm{O}_{5} \mathrm{~S}(3,4) ; 10-\mathrm{C}_{15} \mathrm{H}_{19} \mathrm{CuN}_{5} \mathrm{O}_{5} \mathrm{~S}(2,4) ; 11-\mathrm{C}_{18} \mathrm{H}_{22} \mathrm{Cl}_{2} \mathrm{Cu}_{2} \mathrm{~N}_{8} \mathrm{~S}_{2} ; 12-\mathrm{C}_{9} \mathrm{H}_{11} \mathrm{ClCuN}_{4} \mathrm{~S}$; $\mathrm{M}$ - untreated culture.

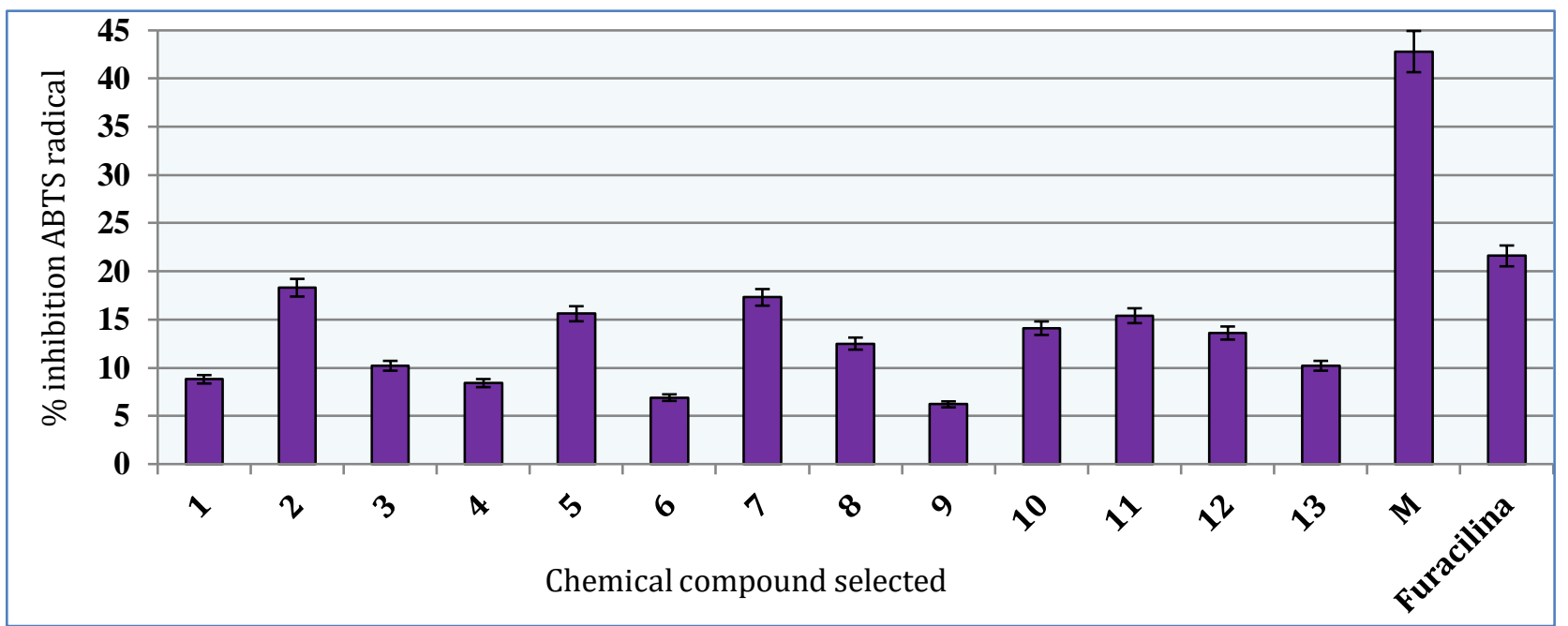

Figure 2. Alterations of total antioxidant capacity in Bacillus cereus ГИСК $8035 \mathrm{~S}$ strain under the influence of new chemical compounds: $1-\mathrm{C}_{38} \mathrm{H}_{38} \mathrm{Cu}_{2} \mathrm{~N}_{14} \mathrm{O}_{10} \mathrm{~S}_{4} ; 2-\mathrm{C}_{42} \mathrm{H}_{42} \mathrm{Cu}_{2} \mathrm{~N}_{14} \mathrm{O}_{12} \mathrm{~S}_{4} ; 3-$ $\mathrm{C}_{46} \mathrm{H}_{46} \mathrm{Cu}_{2} \mathrm{~N}_{18} \mathrm{O}_{10} \mathrm{~S}_{6} ; 4-\mathrm{C}_{46} \mathrm{H}_{42} \mathrm{Cu}_{2} \mathrm{~N}_{18} \mathrm{O}_{10} \mathrm{~S}_{4} ; 5-\mathrm{C}_{15} \mathrm{H}_{19} \mathrm{ClCuN}_{4} \mathrm{O}_{2} \mathrm{~S} ; 6-\mathrm{C}_{15} \mathrm{H}_{19} \mathrm{CuN}_{5} \mathrm{O}_{5} \mathrm{~S} ; 7-\mathrm{C}_{15} \mathrm{H}_{17} \mathrm{ClCuN} 4 \mathrm{OS} ; 8$ $\mathrm{C}_{15} \mathrm{H}_{19} \mathrm{CuN}_{5} \mathrm{O}_{5} \mathrm{~S}(2,5) ; 9-\mathrm{C}_{15} \mathrm{H}_{19} \mathrm{CuN}_{5} \mathrm{O}_{5} \mathrm{~S}(3,4) ; 10-\mathrm{C}_{15} \mathrm{H}_{19} \mathrm{CuN}_{5} \mathrm{O}_{5} \mathrm{~S}(2,4) ; 11-\mathrm{C}_{18} \mathrm{H}_{22} \mathrm{Cl}_{2} \mathrm{Cu}_{2} \mathrm{~N}_{8} \mathrm{~S}_{2} ; 12$ $\mathrm{C}_{9} \mathrm{H}_{11} \mathrm{ClCuN} 4 \mathrm{~S} ; 13-\mathrm{C}_{10} \mathrm{H}_{13} \mathrm{CuN}_{5} \mathrm{O}_{4} \mathrm{~S}_{2} ; \mathrm{M}$ - control strains.

The total antioxidant capacity of cell lysate from untreated Bacilus cereus culture made up 43.8\% of inhibited ABTS cation radical. This index is quite high even for plant extracts, which are considered the most active one. Treatment of Bacillus cereus culture with Furacillin caused a two- fold decrease in the total antioxidant capacity of the cell extract. The antioxidant capacity shows a higher decrease under the influence of new chemical compounds. Thus, the antioxidant capacity of the lysates made up $14.5-40.4 \%$ of the total capacity of the control sample, depending 
on the compound used.

Bacillus cereus ГИСК 8035 reference strain showed a significant decrease in the ability to remove radicals produced in the biological system, which suggested the inability of the culture to protect itself effectively under oxidative stress caused by the impaired activity of new chemicals.

The study results of the total antioxidant capacity assay of the lysates in Shigella sonnei ATCC 25931 that underwent treatment with equal MIC value dosage of new chemical compounds are presented in Figure 3.

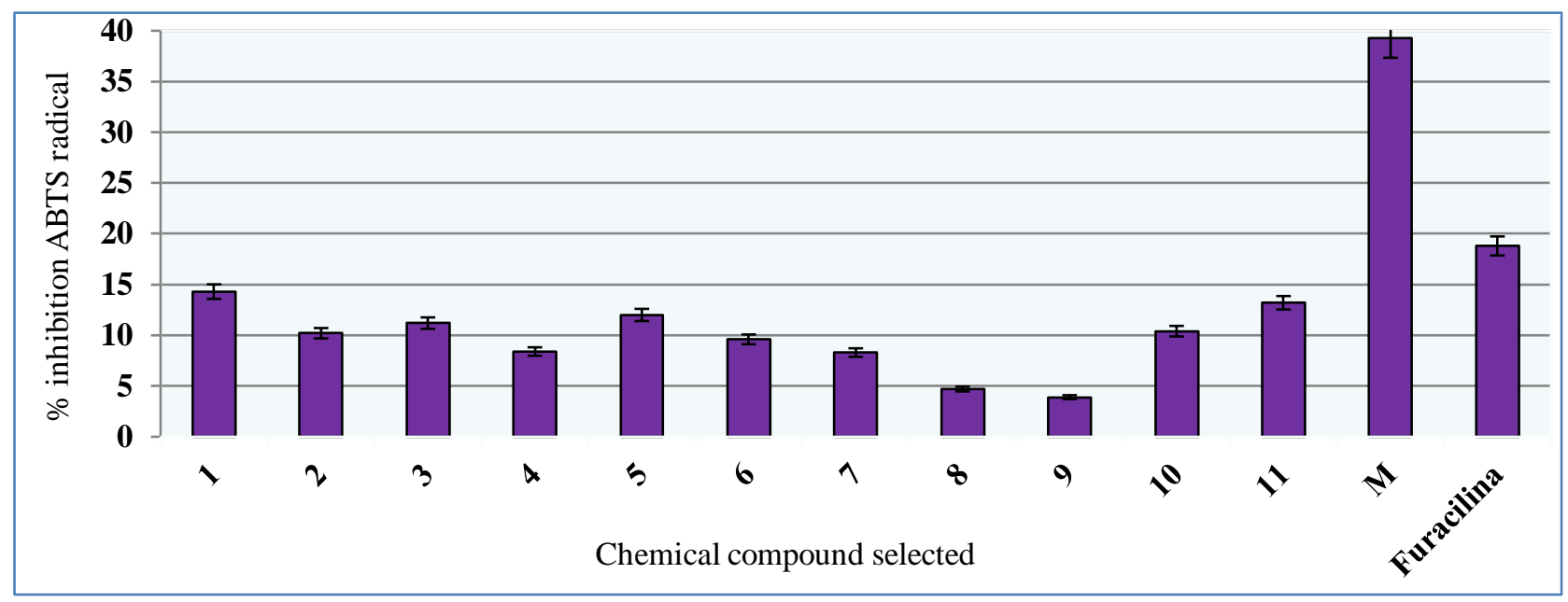

Figure 3. Total antioxidant capacity in standard Shigella sonnei ATCC 25931 culture under the influence of the following new chemical compounds: $1-\mathrm{C}_{38} \mathrm{H}_{38} \mathrm{Cu}_{2} \mathrm{~N}_{14} \mathrm{O}_{10} \mathrm{~S}_{4} ; 2-\mathrm{C}_{42} \mathrm{H}_{42} \mathrm{Cu}_{2} \mathrm{~N}_{14} \mathrm{O}_{12} \mathrm{~S}_{4} ; 3-$ $\mathrm{C}_{44} \mathrm{H}_{40} \mathrm{Cl}_{2} \mathrm{Cu}_{2} \mathrm{~N}_{14} \mathrm{O}_{4} \mathrm{~S}_{6} ; 4-\mathrm{C}_{15} \mathrm{H}_{19} \mathrm{ClCuN}_{4} \mathrm{O}_{2} \mathrm{~S} ; 5-\mathrm{C}_{15} \mathrm{H}_{19} \mathrm{CuN}_{5} \mathrm{O}_{5} \mathrm{~S} ; 6-\mathrm{C}_{15} \mathrm{H}_{17} \mathrm{ClCuN}_{4} \mathrm{OS} ; 7$ $\mathrm{C}_{15} \mathrm{H}_{19} \mathrm{CuN}_{5} \mathrm{O}_{5} \mathrm{~S}(2,5) ; 8-\mathrm{C}_{15} \mathrm{H}_{19} \mathrm{CuN}_{5} \mathrm{O}_{5} \mathrm{~S}(3,4) ; 9-\mathrm{C}_{15} \mathrm{H}_{19} \mathrm{CuN}_{5} \mathrm{O}_{5} \mathrm{~S}(2,4) ; 10-\mathrm{C}_{18} \mathrm{H}_{22} \mathrm{Cl}_{2} \mathrm{Cu}_{2} \mathrm{~N}_{8} \mathrm{~S}_{2} ; 11-$ $\mathrm{C}_{9} \mathrm{H}_{11} \mathrm{ClCuN}_{4} \mathrm{~S} ; \mathrm{M}$ - untreated culture.

The total antioxidant capacity assay in Gramnegative bacterial cultures showed the same decreasing effects in the tested compounds. Thus, Shigella sonnei ATCC 25931 reference strain under normal conditions exhibited a reduced ABTS cation radical capacity of about $40 \%$, however, being a very good indicator. The level of antioxidant activity in Furacillin-treated biomass was twice lower compared to the control sample activity, accounting for $47.8 \%$. The biomass treated with MIC doses of new chemical compounds, the values varied between 3.9 and $14.3 \%$ inhibition that was $9.9-36.4 \%$ of the values characteristic to the control sample.

The results of ABTS assay for di ( $\mu$-S) - bis \{nitrate-[2-picoliden-4-(3,4-dimethylphenyl) thiosemicarbazide-(1-)] copper $\}$ tetrahydrate and di $(\mu-S)$ - bis \{nitrate-[2-picoliden-4-(2,4-dimethylphenyl) thiosemicarbazide- (1-)] copper\} tetrahydrate, were 4.7 and $3.9 \%$ inhibition of ABTS radical cation, respectively. In these cases, the total antioxidant capacity of the culture was reduced to $88-90 \%$, thus leading to blockage of almost all cellular protection responses and structural damage of micromolecular components with antioxidant properties. Therefore, it is obviously clear that under such conditions, the oxidative stress had a highest value in the tested culture, which is crucial for vital processes of the pathogen cells.

The test results regarding the action of the selected compounds on the antioxidant activity of Escherichia coli ATCC 25922-reference culture are presented in Figure 4.

The Escherichia coli ability to reduce the ABTS cation radical under normal conditions made up $36 \%$ inhibition. About a twofold decrease of the total antioxidant capacity was reported in the culture treated with Furacillin, the inhibition percentage being of 18.9 in absolute values and $52.5 \%$, compared to the control sample activity. A significant decrease in antioxidant activity was found in treatment of Escherichia coli ATCC 25922 - reference strain with selected chemical compounds, however, not as significant as in Shigella sonnei strain. 


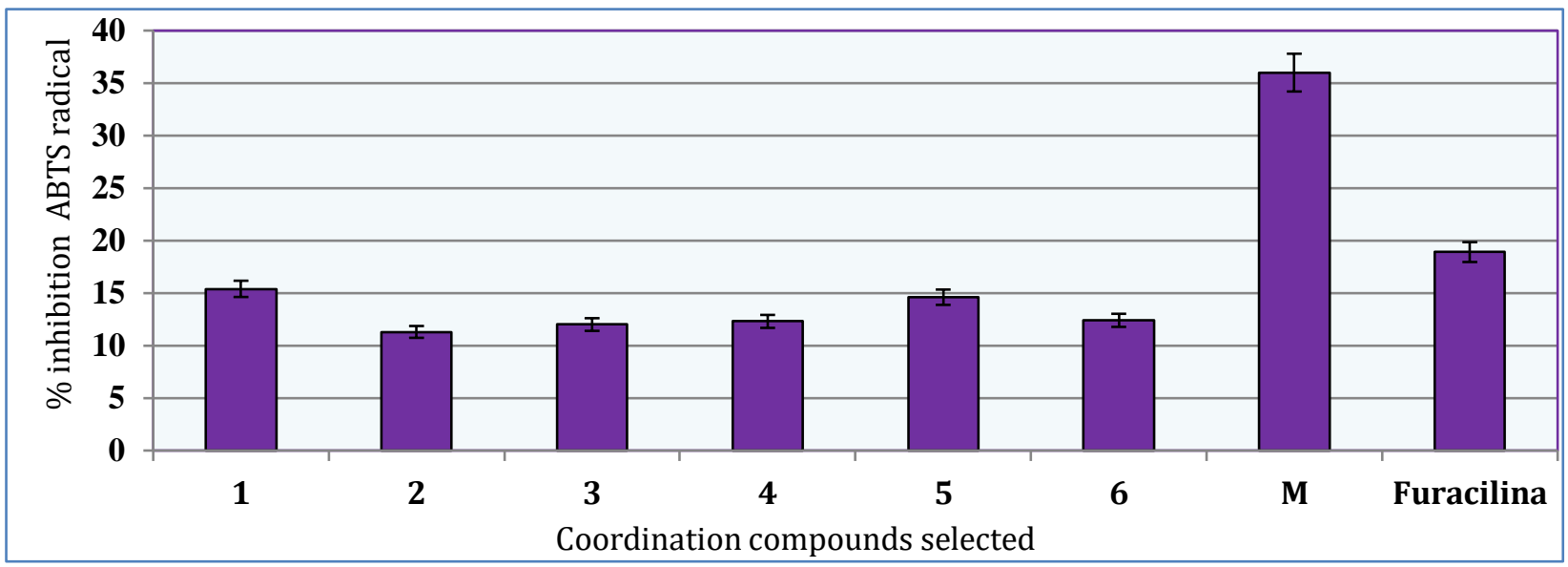

Figure 4. Total antioxidant capacity in standard culture of Escherichia coli ATCC 25922 under the influence of the following new chemical compounds: $1-\mathrm{C}_{38} \mathrm{H}_{38} \mathrm{Cu}_{2} \mathrm{~N}_{14} \mathrm{O}_{10} \mathrm{~S}_{4} ; 2-\mathrm{C}_{44} \mathrm{H}_{40} \mathrm{Cl}_{2} \mathrm{Cu}_{2} \mathrm{~N}_{14} \mathrm{O}_{4} \mathrm{~S}_{6} ; 3-$ $\mathrm{C}_{46} \mathrm{H}_{46} \mathrm{Cu}_{2} \mathrm{~N}_{18} \mathrm{O}_{10} \mathrm{~S}_{6} ; 4-\mathrm{C}_{46} \mathrm{H}_{42} \mathrm{Cu}_{2} \mathrm{~N}_{18} \mathrm{O}_{10} \mathrm{~S}_{4} ; 5-\mathrm{C}_{18} \mathrm{H}_{22} \mathrm{Cl}_{2} \mathrm{Cu}_{2} \mathrm{~N}_{8} \mathrm{~S}_{2} ; 6-\mathrm{C}_{9} \mathrm{H}_{11} \mathrm{ClCuN}_{4} \mathrm{~S} ; \mathrm{M}$ - untreated culture.

Therefore, the reduction capacity of the ABTS cation radical in the bacterial lysate obtained from cultures treated with new chemical compounds decreased by 57.6-68.6\% compared to the lysate capacity obtained from the control biomass samples. This reduction is characteristic for active compounds used against Escherichia coli.

The Escherichia coli reference culture partially retains the antioxidant protection capacity, which has been confirmed by previous studies where the MIC and CBI values of the active com- pounds compared against this culture were higher compared to other studied strains. However, a reduced total antioxidant capacity of the bacterial lysate by at least $57.3 \%$, following a new antibacterial compound treatment reported a significant oxidative stress, thus seriously affecting the vitality of the bacterial culture.

The study results obtained in the treatment of Salmonella enterica ( $S$. Abony ГИСК 03/03y) reference strain with the definite doses of the two active compounds are presented in Figure 5.

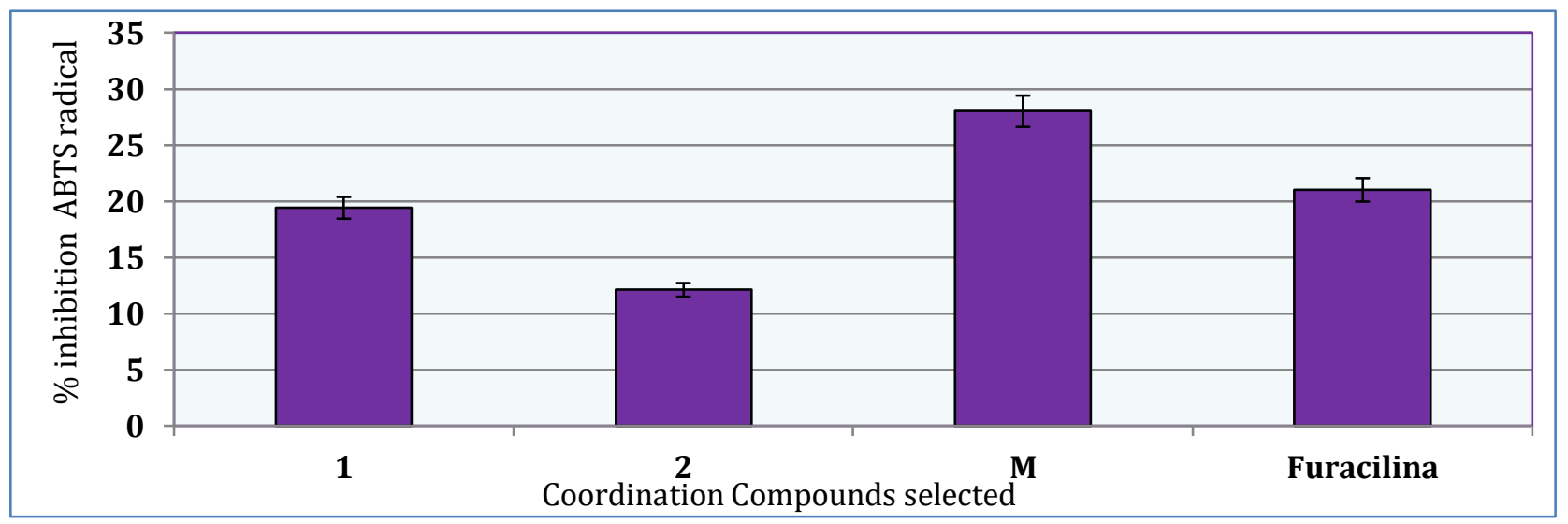

Figure 5. Total antioxidant capacity in standard Salmonella enterica (S. Abony ГИСК 03/03 у) under the influence of the following new chemical compounds: $1-\mathrm{C}_{38} \mathrm{H}_{38} \mathrm{Cu}_{2} \mathrm{~N}_{14} \mathrm{O}_{10} \mathrm{~S}_{4}$;

$2-\mathrm{C}_{44} \mathrm{H}_{40} \mathrm{Cl}_{2} \mathrm{Cu}_{2} \mathrm{~N}_{14} \mathrm{O}_{4} \mathrm{~S}_{6} ; \mathrm{M}$ - untreated culture.

Total antioxidant activity of Salmonella culture under normal conditions was $28 \%$ inhibition of ABTS cation radical, thus showing lower values than the previously studied cultures. The action of Furacillin on the culture leads to a reduced antiradical capacity by $25 \%$ compared to the control samples. The selected compounds have a higher impact on the reduction of antioxidant capacity by $30.7-56.8 \%$ compared to the control sample. 


\section{DISCUSSIONS}

The analysis of the obtained results revealed that the newly selected chemical compounds considerably decrease the total antioxidant capacity in the reference cultures studied.

The highest-intensity effect in reducing the antioxidant capacity of Staphylococcus aureus ATCC 25923 strains was reported in the group of coordination compounds of $\mathrm{Cu}$ (II) with 4(dimethylphenyl) thiosemicarbazone 2-formylpyridine (compounds 5, 6, 8-10), as well as in di $(\mu-S)$-bis \{chloro-[1-(pyridin-2-yl) ethanon-4methylthiosemicarbazonate (1-)] copper\} which produced a significant decrease in antioxidant capacity.

The most pronounced effect in reducing the antioxidant capacity of the Bacillus cereus ГИСК 8035 reference strain was found in di $(\mu-S)$-bis \{nitrato-[2-picoliden-4-(2,6-dimethylphenyl) thiosemicarbazido-(1-)] copper $\}$ tetrahydrate and di $(\mu-S)$-bis \{nitrate-[2-picolidene-4-(3,4dimethylphenyl) thiosemicarbazido - (1-)] copper\} tetrahydrate, which are included in the group of coordination compounds of $\mathrm{Cu}$ (II) with 4 - (dimethylphenyl) thio semicarbazone 2 -formylpy-ridine.
The most active compounds with antibacterial activity against the Shigella sonnei ATCC 25931 reference strain were found in di $(\mu-S)$-bis nitrate-[2-picolidene-4-(3,4-dimethylphenyl) thiosemicarbazido- (1)] copper\} tetrahydrate and di $(\mu-S)$-bis \{nitrate-[2-picoliden-4-(2,4-dimethylphenyl) thiosemicarbazido-(1-)] copper\} tetrahydrate, which are both included in $\mathrm{Cu}$ (II) compounds with 4-(dimethylphenyl) thiosemicarbazone 2-formylpyridine.

It is worth mentioning that most antioxidant compounds against Escherichia coli ATCC 25922 strains belong to the group of $\mathrm{Cu}$ (II) compounds with 4-phenylthiosemicarbazone 2-formylpyridine and sulfanylamides. The ABTS assay values were comparable for assessing other reference strains.

The study findings have proven that Salmonella enterica (S. Abony ГИСК 03/03 y) strain is able to provide antioxidant homeostasis, thus being less vulnerable to the action of compounds, which compared to other reference strains are considered as highly effective antibacterial substances.

\section{CONCLUSIONS}

1. The analysis of the study results have proven that the selected compounds might substantially reduce the total antioxidant capacity in the reference cultures studied.

2. Oxidative stress occurs within the reference cultures, namely, Staphylococcus aureus ATCC 25923, Bacillus cereus ГИСК 8035, Escherichia coli AТСС 25922, Shigella sonnei AТСС 25931 and Salmonella enterica (S. Abony ГИСК 03/03y) under the action of novel antimicrobial chemical compounds.

3. The selected compounds might considerably reduce the total antioxidant capacity in the reference cultures studied. Staphylococcus aureus ATСС 2592 and Bacillus cereus ГИСК 8035 were found to be the most vulnerable to high-intensity oxidative stress, whereas Salmonella enterica (S. Abony ГИСК 03/03y) was the most resistant reference culture.

4. The specific activity of new chemical compounds on primary antioxidant enzymes, which refers as one of the pathogenic factors for disease-causing agents, allows assuming the in vivo effectiveness of the new native substances and thus, recommending the selected compounds for further biomedical tests.

\section{CONFLICT OF INTERESTS}

Nothing to declare.

\section{REFERENCES}

1. Lemire JA, Harrison JJ, Turner RJ. Antimicrobial activity of metals: mechanisms, molecular targets and application. Nature Reviews. Microbiology. 2013;13:371-384.
2. Gulya AP, Chumakov YuM, Tsapkov VI, Graur VO, Lozan-Tyrshu KS, Janno E, et al. Synthesis, structure, and properties of coordination compounds of copper (II) acetate with substituded 2-\{[2-(2-hydroxyethylamino) etylamino]metyl $\}$ phenol. Russian Journal of General Chemistry. 2011;81(9):1859-1866.

3. Gulya AP, Lozan-Tyrshu KS, Tsapkov VI, Chumakov YuM, Zhanno E, Rudik VF. Synthesis, 
structure, and microbial activity of copper (II) chelates containg imidazole and condensation products of $\alpha$ - amino acids with salicylaldehyde and its derivates. Russian Journal of General Chemistry. 2013;83(3):530-537.

4. Gulya AP, Lozan-Tyrshu KS, Korzha ID, Rudik VF. Coordination compounds of Copper with 2Formiylpyridine 4-(Dymethylphenyl) thiosemicarbazones. Russian Journal of General Chemistry. 2012;82(11):1869-1872.

5. Iacovidis I, Delimaris I, Piperakis M. Copper and its complexes in medicine: a bio-chemical approach. Molecular Biology International. 2011. doi:10.4061/2011/594529

6. Lebon F. et al. Metal-organic compounds: a new approach for drug discovery: N1-(4-methyl2pyridyl)-2,3,6-trimethoxybenzamide copper (II) complex as an inhibitor of human immunode-

Date of receipt of the manuscript: $17 / 06 / 2020$

Date of acceptance for publication: 22/07/2020 ficiency virus 1 protease. Biochem Pharmacol. 2002;63(10):1863-73.

7. Noyce JO, Michels H, Keevil CW. Inactivation of influenza A virus on copper versus stainless steel surfaces. Appl Envir Microbiology. 2007;73(8):2748-2750.

8. Re R. et al. Antioxidant activity applying an improved ABTS radical cation decolorization assay. Free Radical Biology and Medicine. 1999;10:1231-1237.

9. Saxena S, Gomber Ch. Superoxide dismutase, protease and lipase expression in clinical isolates of Staphylococcus aureus: a tool for antimicrobial drug discovery. Mol Cell Biochem. 2010;341:217223.

10.Singh V, Pal A, Dorokar MP. A polyphenolic flavonoid glabridin: Oxidative stress response in multidrug-resistant Staphylococcus aureus. Free Radical Biology and Medicine. 2015;87:48-57. 